Www.jmscr.igmpublication.org

Index Copernicus Value: 79.54

ISSN (e)-2347-176x ISSN (p) 2455-0450

crossrefDOI: https://dx.doi.org/10.18535/jmscr/v7i2.23

\title{
Role of Neutrophil-to-lymphocyte ratio as a predictor of acute appendicitis
}

\author{
Authors \\ Dr Paul Dhinakaran ${ }^{1}$, Dr Sreeramulu P $\mathbf{N}^{2} *$, Dr Srinivasan $\mathrm{D}^{3}$ \\ ${ }^{1}$ Post graduate Resident, Dept of General Surgery, SDUMC Kolar \\ ${ }^{2}$ Professor \& HOD, Dept of General Surgery, SDUMC Kolar \\ ${ }^{3}$ Associate Professor, Dept of General Surgery, SDUMC Kolar \\ *Corresponding Author \\ Dr Sreeramulu P N \\ Professor \& HOD, Dept of General Surgery, SDUMC Kolar, India
}

\begin{abstract}
Introduction: Acute appendicitis $(A A)$ is the most common surgical abdominal emergency. Diagnosis still remains purely clinical and which is still associated with low specificity, with negative findings intraoperatively. This study is undertaken to find out a biochemical investigation to aid in the diagnosis of Acute Appendicitis.

Materials and Methods: We retrospectively reviewed 70 patients recorded over the period encompassing three years (2015-2017) at RL Jalappa hospital and research centre, Tamaka, Kolar with AAhad a pathology report that confirmed the diagnosis of acute appendicitis.

The patients were divided into three groups with group 1 consisting of uncomplicated appendicitis group 2 with complicated appendicitis (perforation and gangrenous), group 3 control group with other causes of abdominal pain for evaluation.

Results: There were 30 patients in group 1, 20 patients in group 2 and 20 patients in the control group (group 3). There were no significant differences between groups in terms of age or gender. Significant differences emerged in leukocyte and NLR. There was a significant difference between group 1 and group 2 in terms of radiological appendix diameter and contamination around the appendix and fluid accumulation $(p=0.001)$. However, a significant difference was not detected between NLR increase and contamination around the appendix, fluid accumulation, or appendix diameter.

Conclusion: We suggest that preoperative NLR is a useful parameter to aid in the diagnosis of acute appendicitis and differentiate between simple and complicated appendicitis, and can be used as an adjunct to the clinical examination.
\end{abstract}

\section{Introduction}

Acute appendicitis is one of the most common emergency conditions encountered in general surgery clinics. ${ }^{1}$ Despite advances in medical technology and growing experience, acute appendicitis is still diagnosed based on clinical findings. A detailed history and thorough physical examination are the first step in the evaluation of acute appendicitis patients. ${ }^{2}$ Most patients present with pain starting from the epigastric region and localizing to the lower right quadrant, nausea, vomiting and loss of appetite, though atypical 
presentations are also common. Delayed diagnosis increases rates of 122 perforation and subsequent morbidity, while early surgical decisions to avoid complications increase the negative appendectomy rate. ${ }^{3}$ The considerably high rates of perforation $(15-45 \%)$ and negative appendectomy (7-25\%) reported in the literature show that despite technological advances and clinical experience, we have yet to establish a foolproof diagnostic approach. $^{2}$

The use of various diagnostic tools may reduce perforation rates, duration of hospital stays, and unnecessary surgeries in patients without acute appendicitis. These diagnostic tests include scoring systems, ultrasonography (USG), computed tomography (CT), magnetic resonance imaging and laparoscopy. ${ }^{4}$ Despite these options, this area remains the subject of intense study for many researchers hoping to develop a more effective diagnostic procedure for acute appendicitis. Their studies have primarily focused on laboratory tests and imaging modalities. To further this aim, in the current study we evaluated the role of the neutrophil-to-lymphocyte ratio (NLR)-a less investigated parameter-in the diagnosis of acute appendicitis, its association with radiologic diameter, and whether it can be used to differentiate complicated appendicitis.

\section{Results}

Of the 70 patients, $50(87.5 \%)$ underwent surgery for presumed appendicitis and 20 (12.5\%) for acute abdomen. After excluding 7 patients whose pathology report indicated normal appendix, the study included 50 patients. There were 20 patients in group 1, 50 patients in group 2, and 20 subjects in the control group group 3. There were no significant differences in age or gender distribution between the groups. Significant differences were observed in leukocyte counts and NLR. Post hoc Tukey test of significance revealed that there were significant differences in leukocyte count between the 3 groups, while the difference in NLR was not significant between groups 1 and 2 but was significant in all other group comparisons (Table 1). Appendectomy was performed using open (McBurney) technique in 93 patients $(88.5 \%)$, laparoscopic in 10 patients $(9.5 \%)$ and umbilical mini-laparotomy in 2 patients (1.9\%). No significant differences emerged between the groups in terms of surgical method. The relatively low rate of laparoscopic appendectomy $(9.5 \%)$ is due to the fact that the laparoscopy instruments in our hospital are not always functional. The laparotomic approach was used in cases where findings of acute abdomen and generalized peritonitis led to suspicion of complicated appendicitis. Akgül and Gündeş, Neutrophil/Lymphocyte Ratio in Acute Appendicitis 123 Akgül and Gündeş, Neutrophil/ Lymphocyte Ratio in Acute Appendicitis Including the patients with normal appendix excluded from the study, the rate of complicated appendicitis was $32.9 \%$. We believe this rate is high because people in the region have difficulty reaching the hospital. The rate of negative appendectomy in our study was $6.25 \%$, consistent with the literature. Although 20 of the 70 patients in our study exhibited contamination or fluid around the cecum and appendix on USG or CT, no contamination or fluid was reported for the other 56. There were significant differences between the groups in radiologic appendix diameter and periappendiceal contamination $(\mathrm{p}=0.001)$. However, elevated NLR was not correlated with periappendiceal contamination or fluid. There was also no correlation between NLR elevation and appendix diameter ( $\mathrm{p}>0.05)$.

Table 1. Distribution of patients according to the NLR cutoff values in the main groups Cutoff value of NLR Negative appendectomy (G2) Positive appendectomy (G1) 4.6877586 Total 170897

\section{Discussion}

Acute appendicitis is the most common cause of acute abdomen among all age groups. The timely and accurate diagnosis of patients presenting to emergency departments with presumed acute appendicitis continues to be a challenge. The 
patient's reported medical history and a physical examination are the foundation of diagnosis. ${ }^{5}$ As a rule, when investigating the etiology of sudden abdominal pain in a previously healthy individual, appendicitis is the first condition that must be excluded. $^{6}$

Anorexia is the first and most constant symptom of appendicitis. If anorexia is absent, the diagnosis of appendicitis should be reconsidered. The order in which symptoms appear is important in the differential diagnosis. Anorexia is the first symptom in $95 \%$ of acute appendicitis patients, followed by abdominal pain and nausea/vomiting. If vomiting occurs before abdominal pain, this is also grounds for questioning an appendicitis diagnosis. ${ }^{8}$ Rebound in the right lower quadrant is one of the cardinal signs, and may be sufficient on its own for a diagnosis, especially in male patients.

White cell count is elevated in cases of acute, uncomplicated appendicitis. Leukocyte count ranges from 10.000-18.000/ $\mathrm{mm} 3$ and the neutrophil ratio is greater than $75 \%$. In about $10 \%$ of patients, leukocyte count may be normal. A white cell count over $20.000 / \mathrm{mm} 3$ suggests gangrenous, perforated appendicitis. ${ }^{9}$

Our results show that NLR with a cutoff value of 4.68 can significantly differentiate a normal appendix and inflamed AA. This value is much higher than the numbers given in previous reports, ${ }^{[9,11]}$ but less than the number reported by Ishizuka et al. ${ }^{[13]}$ The sensitivity of this cutoff value is $65.3 \%$, which means that a total of $65 \%$ of patients with histologically confirmed AA have an elevated ratio. The specificity of $54.7 \%$ is also low (thus a high false-positive rate). These low sensitivity and specificity values may be explained by the fact that only operated patients were included in this study; data about other suspected cases who were not operated or were medically treated are unknown. Another interesting finding is that the female to male ratio is significantly higher in the negative appendectomy group. This may be attributed to gynecological diseases mimicking A
In conclusion, according to the results of our study, NLR of 4.68 seems to be a reliable parameter to obtain a more certain diagnosis of acute appendicitis, and NLR of 5.74 may help to differentiate complicated from non-complicated appendicitis. However, a normal value for NLR does not exclude the diagnosis. To find the optimal NLR and to test its accuracy, prospective randomized studies are needed. The clinical evaluation by the surgeon should continue to take precedence.

\section{References}

1. Brunicardi FC, Andersen DK, Billiar TR. Schwartz's Principles of Surgery. 9th edition, 2010.

2. Başaklar CA. Karın Ağrısıve Akut Apandisit in Bebekve Çocukların Cerrahive Ürolojik Hastalıkları. Palme Yayıncıl1k. Ankara, 2006:991.

3. Eryılmaz R, Şahin M, Alimoğlu O, Baş G, Özkan OV. Negatifapendektomileri Önlemede c-reaktif protein lökositsayım1nındeğeri. Ulus Travma Acil Cerrahi Derg 2011;7:142-145.

4. Binnebösel $M$, Otto J, Stumpf $M$, Mahnken AH, Gassler N, Schumpelick V, Truong S. Acute appendicitis. Modern diagnostics-surgical ultrasound. Chirurg 2009;80:579-587.

5. Benjamin IS, Patel AG. Managing acute appendicitis. BMJ 2002;325:505- 506 Apendiks Hastalıkları. Nobel T1p Kitabevleri. İstanbul, 2002:259-270.

6. Kalaycı G, Acarlı K, Demirkol K. Genel Cerrahi. I. Cilt Akut Apandisitve Apendiks Hastalıkları. Nobel Tip Kitabevleri. İstanbul, 2002:259-270.

7. Courtney M. Townsend, Jr., MD, R. Daniel Beauchamp, MD, B. Mark Evers, MD and Kenneth L. Mattox, MD. Sabiston Textbook of Surgery, 19th Edition 2012. Chapter 51 The Appendix 1279-1293.

8. Sandberg AA, Bahadır MG. Apandisit Üzerine Tarihi Notlar- Akut Apandisitin 
Ayırıc1 Tanısıve Semptomlar. Akut Apandisitte Tanı Tedavive Kanıta Dayalı Cerrahisi. I. Baskı. Avrupa Kitapçılık. İstanbul, 2008:35-65.

9. Wilson EB, Cole JC, Nipper ML, Cooney DR, Smith RW. Computed tomography and ultrasonography in the diagnosis of appendicitis: when are they indicated? Arch Surg 2001;136:670-675.

10. Markar SR, Karthikesalingam A, Falzon A, Kan Y. The diagnostic value of neutrophil: lymphocyte ratio in adults with suspected acute appendicitis. Acta Chir Belg 2010;110:543-7.

11. Yazici M, Ozkisacik S, Oztan MO, Gürsoy H. Neutrophil/lymphocyte ratio in the diagnosis of childhood appendicitis. Turk $\mathbf{J}$ Pediatr 2010;52:400-3.

12. Mason RJ, Moazzez A, Sohn H, Katkhouda N. Meta-analysis of randomized trials comparing antibiotic therapy with appendectomy for acute uncomplicated (no abscess or phlegmon) appendicitis. Surg Infect (Larchmt) 2012;13:74-84. CrossRef

13. Ishizuka $M$, Shimizu $T$, Kubota $K$. Neutrophil-to-Lymphocyte Ratio Has a Close Association With Gangrenous Appendicitis in Patients Undergoing Appendectomy. IntSurg 2012;97:299-304. CrossRef 14. Raftery AT. The value of the leucocyte count in the diagnosis of acute appendicitis. Br J Surg 1976;63:143-4. CrossRef

14. Doraiswamy NV. Leucocyte counts in the diagnosis and prognosis of acute appendicitis in children. $\mathrm{Br} \mathrm{J}$ Surg 1979;66:782-4. CrossRef

15. English DC, Allen W, Coppola ED, Sher A. Excessive dependence on the leukocytosis cue in diagnosing appendicitis. Am Surg 1977;43:399-402. 17. Sasso RD, Hanna EA, Moore DL. Leukocytic and neutrophilic counts in acute appendicitis. Am J Surg 1970; 120:563-6. CrossRef 